\title{
Growth suppression of human breast carcinoma stem cells by lipid peroxidation product 4-hydroxy-2-nonenal and hydroxyl radical-modified collagen ${ }^{\star}$
}

\author{
Ana Cipak1, Lidija Mrakovcic'1, Milan Ciz², Antonin Lojek², Boryana Mihaylova³, Ivan Goshev³, \\ Morana Jaganjac' ${ }^{1}$, Marina Cindric ${ }^{4}$, Sanda Sitic ${ }^{5}$, Marko Margaritoni ${ }^{6}$, Georg Waeg ${ }^{7}$, Marija \\ Balic ${ }^{8}$ and Neven Zarkovic ${ }^{1 凶}$ \\ ${ }^{1}$ Rudjer Boskovic Institute, Department of Molecular Medicine, Zagreb, Croatia; ${ }^{2}$ nnstitute of Biophysics AS CR, Department of Free Radical \\ Pathophysiology, Brno, Czech Republic; ${ }^{3}$ nnstitute of Organic Chemistry with Centre of Phytochemistry, Bulgarian Academy of Sciences, Sofia, \\ Bulgaria; ${ }^{4}$ University of Zagreb Medical School, Department of Pathology, Clinical Hospital Centre, Croatia; 5 University Hospital for Tumors, Za- \\ greb, Croatia; ${ }^{6}$ Dubrovnik Hospital, Surgical Clinic, Research Unit, Dubrovnik, Croatia; 7 Karl Franzens University Graz, Institute of Molecular Bio- \\ sciences, Graz, Austria; ${ }^{8}$ Medical University Graz, Department of Internal Medicine, Division of Oncology, Graz, Austria
}

Breast cancer is a leading cause of mortality and morbidity in women, mostly due to high metastatic capacity of mammary carcinoma cells. It has been revealed recently that metastases of breast cancer comprise a fraction of specific stem-like cells, denoted as cancer stem cells (CSCs). Breast CSCs, expressing specific surface markers $\mathrm{CD}_{4}{ }^{+} \mathrm{CD} 24^{-/ l o w} \mathrm{ESA}^{+}$usually disseminate in the bone marrow, being able to spread further and cause late metastases. The fundamental factor influencing the growth of CSCs is the microenvironment, especially the interaction of CSCs with extracellular matrix (ECM). The structure and function of ECM proteins, such as the dominating ECM protein collagen, is influenced not only by cancer cells but also by various cancer treatments. Since surgery, radio and chemotherapy are associated with oxidative stress we analyzed the growth of breast cancer CD44+CD24-/lowESA ${ }^{+}$cell line SUM159 cultured on collagen matrix in vitro, using either native collagen or the one modified by hydroxyl radical. While native collagen supported the growth of CSCs, oxidatively modified one was not supportive. The SUM159 cell cultures were further exposed to a supraphysiological $(35 \mu \mathrm{M})$ dose of the major bioactive lipid peroxidation product 4-hydroxynonenal (HNE), a well known as "second messenger of free radicals", which has a strong affinity to bind to proteins and acts as a cytotoxic or as growth regulating signaling molecule. Native collagen, but not oxidised, abolished cytotoxicity of $\mathrm{HNE}$, while oxidized collagen did not reduce cytotoxicity of HNE at all. These preliminary findings indicate that beside direct cytotoxic effects of anticancer therapies consequential oxidative stress and lipid peroxidation modify the microenvironment of CSCs influencing oxidative homeostasis that could additionally act against cancer.

Keywords: SUM159, breast cancer stem cells, 4-hydroxynonenal, extracellular matrix, collagen, oxidative homeostasis

Received: 10 November, 2010; revised: 08 June, 2010, accepted: 15 June, 2010; available on-line: 17 June, 2010

\section{INTRODUCTION}

In spite of the huge progress in the diagnostics and treatment of cancer in the last few decades, breast cancer still represents a leading cause of mortality and mor- bidity in women (Jemal et al., 2006). The reasons for that are the high incidence of mammary carcinoma and specific biological/clinical features of breast cancer related to the spread and recurrence of malignant cells that are still not well understood. Hence, the survival curves of breast cancer patients reach a plateau after 7 to 10 years, unlike most of other cancer patients with a plateau after 2 to 5 years (Hadden, 1999). Length of time required to reach the plateau is due to the ability of primary tumor to develop metastases even years after removal of the primary carcinoma (Jemal et al., 2006). Tumor cells disseminated to bone marrow are regarded as biomarkers of early metastatic spread determining development of the metastases of mammary carcinoma (Braun et al., 2005). Namely, it was shown that the majority of these disseminated tumor cells have a putative breast cancer stem cell phenotype (Balic, 2009). It took several decades to reveal that metastases consist of disseminated tumor cells with a fraction of stem-like cells, usually anchored in the bone marrow before spreading as late metastases (Balic et al., 2006). These particular breast cancer stem cells are denoted as cancer stem cells (CSCs), which are of great importance in cancer biology as they are involved in blood vessel formation, promotion of cell motility and resistance to therapies and especially to metastasis development (Balic et al., 2006; Charafe-Jauffret et al., 2008). The minimal surface marker expression, associated with $\mathrm{CSC}$ in breast cancer, is $\mathrm{CD} 44^{+} \mathrm{CD} 24^{-/ \text {low ESA }}{ }^{+}$(Al-Hajj et al., 2003). The proportion of cells with this specific expression pattern correlates with tumorigenicity and aggressive behavior. In addition, $\mathrm{CD} 44^{+} \mathrm{CD} 24^{-/ \text {low }} \mathrm{ESA}{ }^{+}$ CSC recapitulate the histology, progression, and metastatic spread of the disease (Fillmore \& Kuperwasser, 2008).

A crucial factor influencing the stem cell destiny is their microenvironment (niche) (Li \& Xie, 2005). The main function of the niche is to prevent tumorigenesis and to control the stem cells in the arrested state thereby

$\triangle$ e-mail: zarkovic@irb.hr

^ Presented at the COST B-35 Work Group 4 Open Workshop "Natural and synthetic antioxidants", September 25-26, 2009, Rzeszów, Poland.

Abbreviations: CSC, cancer stem cells; ECM, extracellular matrix; HNE, 4-hydroxy-2-nonenal; MMP, matrix metalloproteinase; OF/LB, onco-foetal/laminin-binding; PS, polystyrene; ROS, reactive oxygen species. 
maintaining the homeostasis. Stem cells are implicated in the homeostatic processes of the breast as a dynamic gland changing its structure and function during early development, puberty, within menstrual cycles, during pregnancy and lactation, and eventual involution during menopause (Morrison et al., 2008). Homeostasis of stem cells in the breast is achieved through interactions with fibroblasts and myoepithelial cells on one hand and with extracellular matrix (ECM) on the other (Gudjonsson et al., 2002). Processes like chronic inflammation affecting stromal cells and ECM could, therefore, cause transformation with uncontrolled proliferation and expansion of breast cancer stem cells (Spradling et al., 2001; Tumbar et al., 2004). Therefore, deregulation of the niche may play a role in reinduction of the CSC proliferation, while CSCs may be capable of escaping the niche control when they become independent from the niche signaling ( $\mathrm{Li} \& \mathrm{Xie}, 2005)$. Hence, changes in adhesion molecule expression and re-appearance of OF/LB (onco-foetal/laminin-binding) collagen is observed in breast cancer (Sirchia \& Luparello, 2005; Borrirukwanit et al., 2007), indicating that collagen is an important factor in tumorigenesis and metastasis formation. Namely, collagen forms ECM dominated by cross-linked networks of collagen type I, which is the major extracellular protein found in mammals and forms a biological barrier defending normal tissue from aggressive pathologies, such as toxic agents, infections and cancer (Brown et al., 2003; Sabeh et al., 2004). To penetrate this structural barrier, cancer cells have developed two distinct mechanisms, protease-dependent or protease-independent invasion (Sabeh et al., 2004; Li et al., 2008; Pinner \& Sahai, 2008). Protease-dependent invasion occurs via secretion of matrix metalloproteinase family members which degrade collagen fibres (Sabeh et al., 2004). Protease-independent invasion includes amoeboid-like behavior where tumor cells physically displace matrix fibrils, adopting thereby amoeboid shape and moving along and through collagen fibres (Wolf et al., 2003; Pinner \& Sahai, 2008; Sabeh et al., 2009).

On the other hand, while it is well know that tumor development is also strongly influenced by oxidative stress, there no study yet has evaluated the relevance of oxidative stress for the breast cancer stem cells (BCSCs). Tumor cells have compromised antioxidative mechanisms and higher content of reactive oxygen species (ROS) creating conditions of persistent oxidative stress (Toyokuni et al., 1995). ROS, in particular the most aggressive hydroxyl radical, act on cell macromolecules causing DNA damage, protein modifications and lipid peroxidation (Uchida et al., 1993). Final products of lipid peroxidation are reactive aldehydes, with trans-4-hydroxy2-nonenal (HNE) being the most intensively studied as a toxic second messenger of free radicals (Zarkovic N., 2003; Uchida, 2003). HNE has been found to play an important role in pathology of various diseases like Alzheimer's disease, Parkinson's disease, atherosclerosis, cancer, diabetes, autoimmune diseases and bone diseases (Selley et al., 1992; Yoritaka et al., 1996; Sayre et al., 1997; Poli \& Schaur 2000; Zarkovic, 2003a). However, HNE may also act as a signaling molecule not only under physiological conditions but also in pathological ones and is, therefore, considered also a major 'bioactive marker of pathophysiological processes' associated with lipid peroxidation (Zarkovic, 2003b). Which of these effects, cytotoxicity or growth regulation, dominates depends in particular on the HNE concentration and microenvironmental conditions of the growing cells. Under usual in vitro conditions as well as for most tissues studied, $1 \mu \mathrm{M}$ to $10 \mu \mathrm{M}$ HNE may be considered as physiological, above $10 \mu \mathrm{M}$ supraphysiological and moderately toxic, while above $50 \mu \mathrm{M} \mathrm{HNE}$ is highly cytotoxic reaching its $\mathrm{LD}_{50}$ or even $\mathrm{LD}_{100}$ effect (Esterbauer et al., 1991; Zarkovic et al., 2009).

There is a growing body of evidence for an involvement of lipids, lipid metabolism and lipid peroxidation in breast cancer development (Boyd \& McGuire, 1991; Kökoğlu et al., 1994; Ray \& Husain, 2001). However, since BCSCs were discovered only recently, we lack information on the growth of these cells under the influence of lipid peroxidation, which might help to understand better the specific malignant biology of breast cancer and especially the influence of oxidative stress and lipid peroxidation on the viability of these cells. That might be particularly important because current cancer therapies induce oxidative stress, as in the case of radiotherapy and the frequently used doxorubicin therapy of breast cancer. Thus, the aim of the present study was to investigate the influence of $\mathrm{HNE}$ on the growth of human breast cancer stem cells cultured on either native or on oxidatively modified collagen resembling ECM microenvironment affected by oxidative stress.

\section{MATERIALS AND METHODS}

Materials. All chemicals were purchased from Sigma (Austria) unless stated differently.

Preliminary treatment of raw material. Raw calf hide was subjected to extensive washing with tap water and detergents at room temperature to remove any impurities. Non-collagenous proteins were removed by washing with $0.15 \mathrm{M}$ sodium chloride. The hide was dehaired mechanically and subcutaneous fat was removed. Then, additional de-fatting with chilled acetone was carried out.

Collagen extraction and purification. The treated hide was cut into pieces and soaked in $50 \mathrm{mM}$ acetic acid for $24 \mathrm{~h}$ in the cold. After homogenization, dilution and centrifugation, collagen was obtained by neutralization and salting out according to Miller and Rhodes (1982). The pellet was dissolved in acetic acid, freezedried and stored at $4{ }^{\circ} \mathrm{C}$ at $10 \mathrm{mg} / \mathrm{ml}$ concentration. This material was used as native collagen. The described collagen isolation and purification is highly repeatable and convenient for standardized oxidative treatment as described below (Ciz et al., 2009).

Oxidative treatment with hydroxyl radical $\left(\mathrm{OH}^{*}\right)$. The modification was carried out at $\mathrm{pH}$ about 4.0 (50 $\mathrm{mM}$ acetic acid). The hydroxyl radical was generated according to the Fenton reaction (Imlay et al., 1988) using the system $\mathrm{FeSO}_{4} / \mathrm{H}_{2} \mathrm{O}_{2}$ in effective concentrations $100 \mu \mathrm{M}: 2 \mathrm{mM}$. The duration of the treatment was 18 $\mathrm{h}$ at room temp. After intensive dialysis against diluted acetic acid and centrifugation, the collagen solution was freeze-dried and stored at $4^{\circ} \mathrm{C}$. This sample was termed oxidatively modified calf skin collagen.

Differential scanning calorimetry (DSC). Thermal denaturation of non-modified and modified collagen samples was performed and calorimetric measurements were carried out on a VP-DSC MicroCalorimeter (MicroCal, Inc., USA) with the cell volume of $0.51 \mathrm{ml}$. Data were collected from $10^{\circ} \mathrm{C}$ to $50^{\circ} \mathrm{C}$ at a heating rate of $0.5^{\circ} \mathrm{C}$ per minute. Protein concentrations were measured according to Bradford method (Bradford, 1976) and concentrations were adjusted to $1 \mathrm{mg} / \mathrm{ml}$ in $10 \mathrm{mM}$ 
HCl. All solutions were degassed before measurements. Reference baseline was obtained by buffer $v$ s. buffer scan and subtracted from the measured data. The obtained results were analyzed using the Origin software (Microcal Software, Inc., USA).

Circular dichroism (CD). CD-spectra were obtained for native and oxidized $\left(\mathrm{OH}^{\circ}\right)$ collagen samples at 0.38 $\mathrm{mg} / \mathrm{mL}$ and $0.40 \mathrm{mg} / \mathrm{mL}$ dissolved in $50 \mathrm{mM}$ acetic acid, respectively. The spectra were collected in the range 200-300 $\mathrm{nm}$ at room temp. in $0.5 \mathrm{~mm}$ quartz cuvettes on a Jobin Yvone CD 6 equipment. The baseline (of acetic acid alone) was subtracted.

Dot-blot for HNE-collagen adducts. Collagen and oxidized collagen were re-dissolved in diluted acetic acid $(50 \mathrm{mM})$ in a final concentration of $2 \mathrm{mg} / \mathrm{ml}$. They were further diluted with de-ionized water to be used at $5 \mu \mathrm{g} /$ $\mathrm{cm}^{2}$ for collagen coating and treatment with 10,35 or $50 \mu \mathrm{M}$ HNE for $1 \mathrm{~h}$. After treatment with HNE, 100$\mu l$ samples were spotted onto nitrocellulose membrane (Amersham). The membrane was incubated in blocking solution (2\% nonfat milk powder in PBS) at room temp. for $60 \mathrm{~min}$ and subsequently incubated overnight with mouse monoclonal antibody directed against HNE-histidine epitope as described before (Sovic et al., 2001). The blot was incubated with $3 \% \mathrm{H}_{2} \mathrm{O}_{2}$ to block endogenous peroxidases and then washed and incubated with EnVision (Dako, Denmark) for $30 \mathrm{~min}$. Immune complexes were visualized using the 3,3'-diaminobenzidine tetrahydrochloride (Dako, Denmark) staining and scanned for quantification of signals. Negative controls were included in all experiments in the which tested antibody was omitted and replaced by control diluent (1\% BSA in PBS).

Collagen coating. Freeze-dried collagen samples were dissolved in diluted acetic acid $(50 \mathrm{mM})$ in a final concentration of $2 \mathrm{mg} / \mathrm{ml}$. Collagen coating of 96-well plates (TTP, Trasadingen, Switzerland) was preformed by adding $50 \mu \mathrm{l}$ of collagen dissolved in deionised water to a final concentration of $5 \mu \mathrm{g} / \mathrm{cm}^{2}$. The microwell plate was left to dry in a laminar flow hood overnight and sterilized under UV light for $20 \mathrm{~min}$.

Cell line. Human breast cancer cell line SUM159 was obtained from Asterand (Detroit, MI, USA), and cultured according to supplier's recommendations. Previously, it was shown that these cancer stem cells express $\mathrm{CD}_{4}+/ \mathrm{CD}_{24}-/$ low $/ \mathrm{ESA}^{+}$and are able to form mammospheres (Dontu et al., 2003), which is a specific feature of cancer stem cells. We cultivated our cells in mammosphere-inducing conditions; therefore the SUM159 cells used could be indeed considered as breast cancer stem cells resembling those cancer stem cells which disseminate and cause metastases formation. For the culture of mammospheres viable, floating single cells were collected from the supernatant of confluent breast cancer cell culture and after centrifugation at $125 \times g$ for $5 \mathrm{~min}$ seeded in ultra low attachment flasks (Corning, New York, USA). The culture of mammospheres was performed as previously published (Dontu et al., 2003; Ponti et al., 2005). Briefly, cells were grown in serum-free MEBM (Lonza, Basel, Switzerland) supplemented with $10 \mathrm{ng} /$ $\mathrm{ml}$ basic fibroblast growth factor (bFGF), $20 \mathrm{ng} / \mathrm{ml} \mathrm{epi-}$ dermal growth factor (EGF), $5 \mu \mathrm{g} / \mathrm{ml}$ insulin (all from Peprotech, New York, USA), and $20 \mu \mathrm{l} / \mathrm{ml} \mathrm{B27}$ supplement (Invitrogen).

Cell viability assay. Mammospheres were collected from medium, dissociated by passing the cell suspension through a sterile syringe. The obtained cell suspension was counted, diluted to a density of $10^{4}$ cells/well and seeded in microwell plates coated with native or oxidized collagen, or without collagen. Cells were then treated with $35 \mu \mathrm{M}$ HNE (Alexis, USA) for $24 \mathrm{~h}$ when MTT assay (EZ4U, Biomedica Austria) was done according to manufacturer's instruction (Cazacu et al., 2003). The HNE concentration used was chosen according to literature data which denote $1-10 \mu \mathrm{M}$ HNE as physiological, above $10 \mu \mathrm{M}$ supraphysiological and above $50 \mu \mathrm{M}$ as highly cytotoxic. Hence, $35 \mu \mathrm{M}$ represents a supraphysiological concentration which one may assume could be generated by aggressive radio- or chemotherapy.

Immunocytochemical staining for HNE-protein adducts. Mammospheres were collected from medium and dissociated by passing through sterile syringe. The obtained cell suspension was counted, diluted to a density of $10^{4}$ cells/well and seeded in microwell plates coated with native or oxidized collagen. Cells were left for $1 \mathrm{~h}$ to allow them to adhere, and then were treated with 10,35 or $50 \mu \mathrm{M}$ HNE (Alexis, USA) for $2 \mathrm{~h}$. Cells were the fixed for $2 \mathrm{~min}$ in methanol and formalin. Immunocytochemical staining for HNE-protein was performed as described before (Zarkovic et al., 1997) using EnVision (DAKO, Denmark). Samples were incubated with anti-HNE monoclonal antibodies (dilution $1: 10$ ) for $2 \mathrm{~h}$ in humid chambers at room temp., washed three times for 5 min with phosphate-buffered saline (PBS) and then incubated with biotinylated secondary antibody for $30 \mathrm{~min}$. After washing with Tris-buffered saline (TBS), three times for $5 \mathrm{~min}$, samples were incubated with streptavidin-peroxidase for $30 \mathrm{~min}$. Finally, the reaction was visualized with $\mathrm{DAB}$ (3,3-diaminobenzidine tetrahydrochloride in organic solvent; DAKO, Denmark) giving a brown color that indicated the presence of HNE. Negative control was done without application of the HNE-histidine specific monoclonal antibodies.

\section{RESULTS AND DISCUSSION}

Since extracellular matrix (ECM) contains abundant type I collagen as the major protein component we used calf skin collagen as an adherent surface for breast cancer stem cells. Treatment with hydroxyl radical, the most reactive oxygen free radical, generated from hydrogen peroxide was used to induce oxidative modification of collagen. Thus oxidized collagen and the native one were used as substrate to culture human breast cancer stem cells $\left(\mathrm{CD} 44^{+} \mathrm{CD} 24^{-/ \text {low }^{-}} \mathrm{ESA}^{+}\right)$of the SUM159 cell line with polystyrene (PS) surface as a control. Cells cultivated in this manner were treated with $35 \mu \mathrm{M}$ HNE to further simulate the cancer microenvironment under severe lipid peroxidation as in the case of radio- and chemotherapy. The treatment of collagen with hydroxyl radical induced a modification of collagen that was characterized by a decrease in denaturation temperature (Fig. 1 and Table 1). The differential scanning calorimetry (DSC) scan rates of $0.5-1{ }^{\circ} \mathrm{C} / \mathrm{min}$ showed two denaturation transitions for non-modified collagen at $40.1^{\circ} \mathrm{C}$ (the major denaturation transition) and $33.9^{\circ} \mathrm{C}$ (the minor denaturation transition or pre-transition). The modification of collagen with hydroxyl radical resulted in two denaturation transitions and redistribution of the peak areas - the main denaturation transition occurred at $33.0^{\circ} \mathrm{C}$, while a minor part of the sample denaturated at $40.5^{\circ} \mathrm{C}$. This observation indicates that the oxidative radical treatment affected a major part of the protein causing significant structural changes, still leaving a minor amount of protein intact. A small endothermic transition at $33-35^{\circ} \mathrm{C}$, referred to as "pre-transition", has 

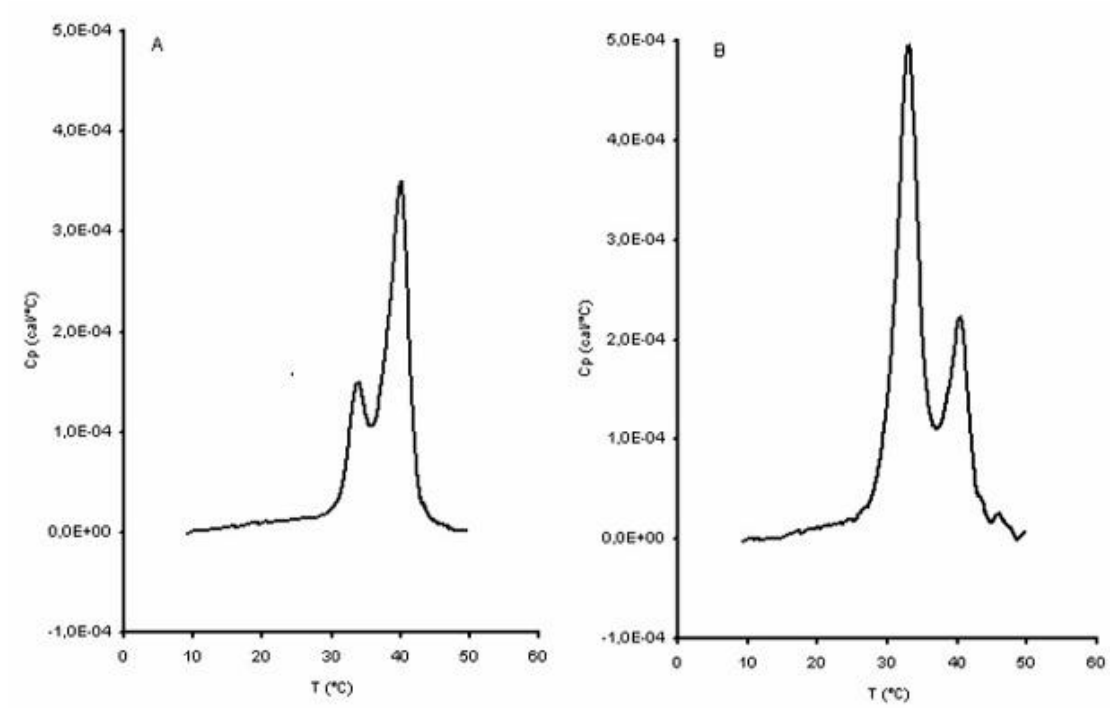

Figure 1. DSC denaturation profiles of non-modified and oxidatively modified calf skin collagen.

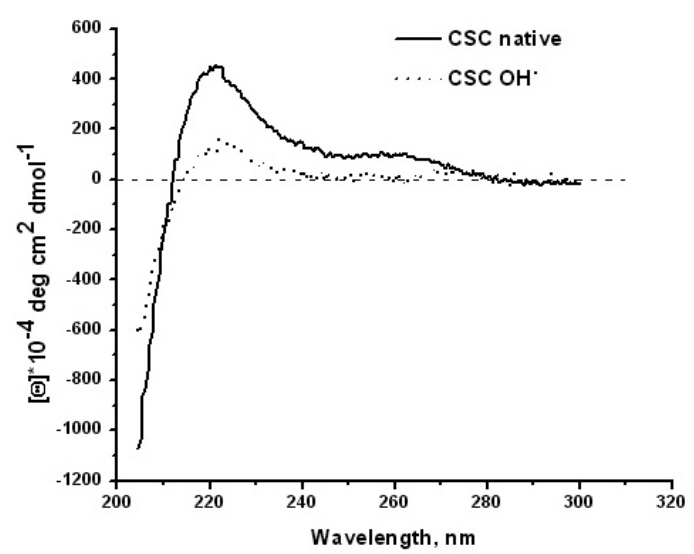

Figure 2. CD spectra of native and oxidized calf skin collagen.

been recorded in several studies (Privalov \& Tiktopulo, 1970; Danielsen, 1982; Wallace et al., 1986; Condell et al., 1988). Although the nature of the structural changes underlying this transition has not been clarified, it seems that the pre-transition is entirely due to collagen oxidation, as discussed in the paper of Komsa-Penkova et al. (1999). In our particular case the sample termed as nonmodified also exhibited this minor pre-transition. This might be a consequence of the quality of the starting material, the isolation procedure, storage conditions of the raw material or its preliminary treatment and could well resemble native condition of collagen. Upon treatment with hydroxyl radical the oxidized collagen showed a pattern which differed from the native collagen by a pronounced re-distribution of peak areas. From the circular dicroism analysis (Fig. 2) it is obvious that the oxidative treatment caused significant structural changes in the collagen molecule. The intensity of the specific band at $222 \mathrm{~nm}$ dropped down indicating approx. 70\% loss

Table 1. Denaturation profiles of calf skin collagen samples

\begin{tabular}{llll}
\hline Type of modification & Parameters & Peak 1 & Peak 2 \\
\hline None & Peak position $\left({ }^{\circ} \mathrm{C}\right)$ & 33.9 & 40.1 \\
& Peak area $(\mathrm{cal})$ & $7.35 \times 10^{-4}$ & $16.23 \times 10^{-4}$ \\
Hydroxyl radical $(\mathrm{OH} \cdot)$ & Peak position $\left({ }^{\circ} \mathrm{C}\right)$ & 33.0 & 40.5 \\
& Peak area $(\mathrm{cal})$ & $26.85 \times 10^{-4}$ & $9.23 \times 10^{-4}$ \\
\hline
\end{tabular}

of native structure. Komsa-Penkova et al. (1999) have shown that oxidative treatment leads to diminishing of the amino-nitrogen content, i.e. modification of the epsilon-amino groups of the lysine amino-acid residues. This is analogous to the physiological aging processes based on the lysyl oxidase action. Highly reactive aldehyde groups are formed, which start the processes of intra- and intermolecular cross-linking. This might lead to limited interaction with growing cells. We also observed reduced collagen solubility after such treatment, which confirms indirectly the mentioned observation. It is well known that the hydroxyl radical is extremely aggressive and therefore it unavoidably attacks proteins present in the reaction medium. The collagen portion affected by hydroxyl radical was very pronounced as obvious from the DSC-profiles (Fig. 2). This phenomenon was observed also by Komsa-Penkova and coworkers.

The viability, as measured by the MTT assay, of the SUM 159 cancer stem cells grown on different surfaces in dependence of exposure to HNE is presented on Fig. 3. In comparison to the PS, native collagen increased the viability of the cells as well as it abolished cytotoxicity of HNE. However, such stimulating and protective effects of collagen were lost if it was oxidized. Namely, HNE treatment of the SUM159 cells cultured on oxidized collagen resulted in a significant decrease of their viability $(P<0.05)$, as if there was no collagen at all, while oxidized collagen itself reduced the viability of the cells in comparison with native collagen. Thus, oxidized collagen cannot support the growth of SUM159 cells and it cannot attenuate the cytotoxic effects of HNE. In agreement with this are also results of analysis of the cell culture morphology presented in Fig. 4. At this point we assumed that native collagen binds HNE and thereby attenuates its toxicity. A major characteristic of $\mathrm{HNE}$ is its high affinity for amino acids, in particular histidine, lysine, cysteine and arginine (Esterbauer et al., 1991). This would reduce the ability of $\mathrm{HNE}$ to bind to cancer cells and reduce their viability. To test this possibility we performed dot-blot analysis for HNE-histidine adducts on oxidized and native collagen (Fig. 5). Surprisingly, the dot-blot showed that oxidized collagen had more HNE-protein adducts compared with native collagen. In order to confirm this observation we per- 


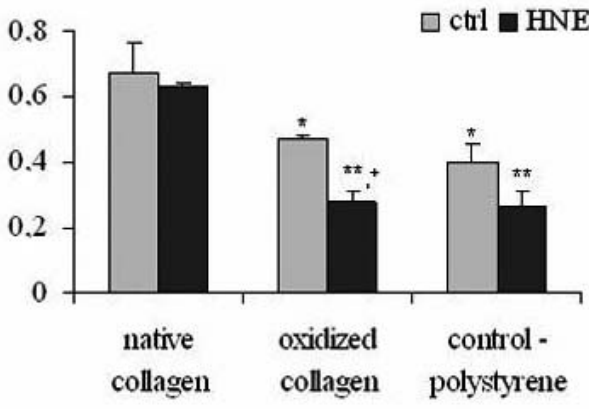

Figure 3. Influence of HNE on SUM159 cell growth on different surfaces.

Native collagen, oxidized collagen, and unmodified polystyrene were used as culture surface. Cell viability was measured by MT assay. ${ }^{*} P<0.05$ compared to control cells grown on native collagen; ${ }^{* *} P<0.05$ compared to HNE-treated cells grown on native collagen, $+P<0.05$ compared to control cells grown on oxidized collagen.

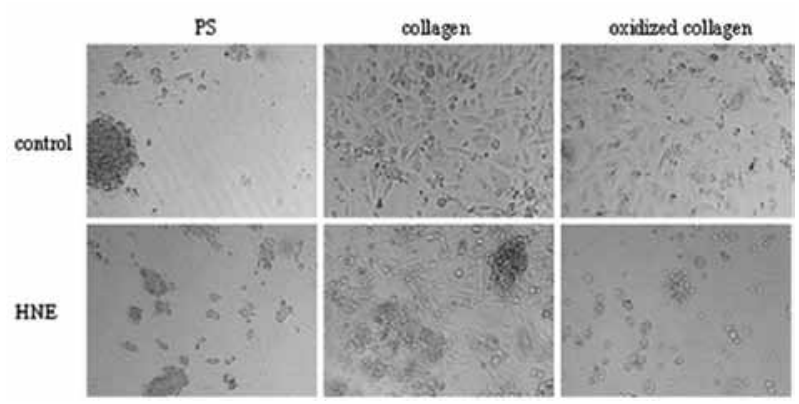

Figure 4. Influence of HNE on SUM159 cell morphology on different surfaces.

Native collagen, oxidized collagen, and unmodified polystyrene were used as culture surface.

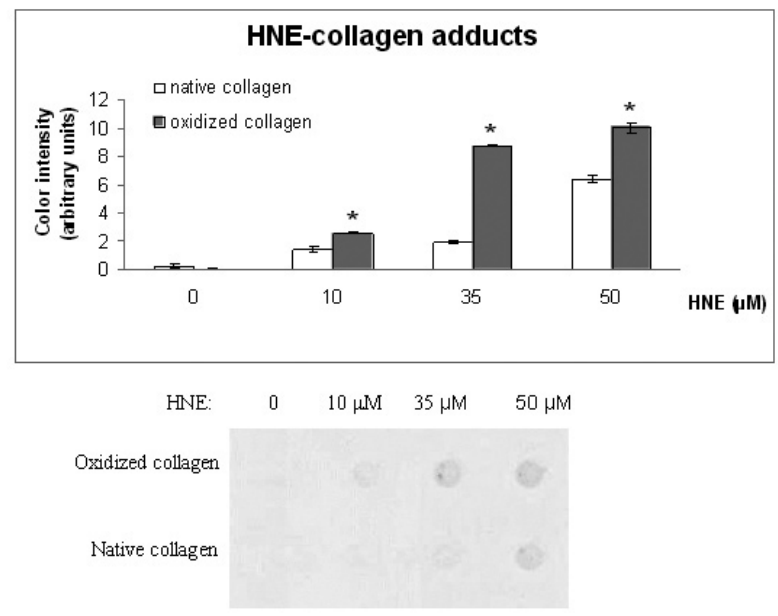

Figure 5. HNE-collagen binding.

Dot-blot analysis of HNE affinity to native or oxidized collagen ${ }^{*} P<0.05$ compared to native collagen treated with the sam concentration of HNE.

formed immunocytochemical staining for HNE-histidine adducts on SUM159 cells cultivated on oxidized or on native collagen and treated with HNE (Fig. 6). These results showed higher HNE-positivity in the cells cultivated on oxidized than on native collagen as analyzed by color intensity. Although contradictory to our initial as-

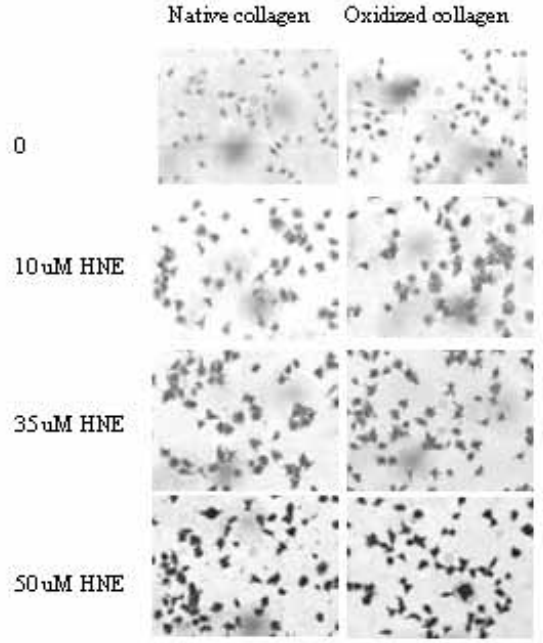

Figure 6. HNE-protein adducts on SUM159 cells cultivated on oxidized or native collagen.

The cells were treated with HNE while the presence of HNE-histidine adducts was determined by specific immunocytochemical staining giving dark colored immunostaining.

sumption, these results explain the lower viability on oxidized collagen. Cells grown on oxidized collagen had a higher content of HNE-protein adducts which probably decreased their viability. On the other hand, treatment with HNE did not influence substantially the growth of cells cultured on native collagen, hence we assume that oxidatively modified collagen upon hydroxyl radical treatment underwent further chain reaction of oxidation that might have affected its affinity for HNE if not fatty acids as well. This possibility will be further studied to evaluate the mechanisms of interaction of lipid peroxidation products and collagen matrix influencing the growth of breast cancer stem cells.

It should be mentioned that the observed effects of HNE could reflect not only direct cytotoxicity of the aldehyde but also a growth regulating effect of HNE in combination with the observed cytotoxicity of oxidized collagen. HNE is well known to act as a growth regulating factor interfering in a dose-dependent manner with cytokines, affecting autocrine and paracrine growth regulation and cellular response to stressful conditions, among which we could also consider oxidation of the surrounding ECM, i.e. collagen as in the case of this study (Zarkovic et al., 1993; 1999; Kreutzer et al., 1998). $\mathrm{HNE}$ binds in particular to membrane-associated proteins and could therefore affect interactions between cancer cells and the surrounding ECM (Sovic et al., 2001; Zarkovic, 2003; Borovic et al., 2008). Since the effects of HNE depend on the intensity of its binding to the proteins, we could assume that HNE could also change the structure and functions of ECM proteins, in particular collagen. If so, it could influence the cells both directly by binding to their membrane-associated proteins and indirectly by changing the proteins of their microenvironment. This possibility will be further evaluated in future studies, because the results of the current study indicate for the first time a potentially crucial role of oxidative stress in modification of cell growth by modified ECM and enhanced cytotoxicity of $\mathrm{HNE}$, in agreement with recent findings on the fundamental importance of ECM in cancer development influencing the shape and behavior of normal, transformed and stem cells (Ingber, 2008). 
Although HNE acts in a concentration-dependent manner as a growth regulating factor when present at low, physiological concentrations or as cytotoxic factor in supraphysiological concentrations, we may assume that in the case of severe oxidative stress that might be induced by radio- and/or chemotherapy of cancer, HNE would act mostly as a cytotoxic factor even if generated below the highly toxic dose. Namely, in the case of oxidative stress the ECM proteins would be modified in a similar way as was collagen modified with hydroxyl radical in this study, hence in the interaction between ECM and surrounding cells, HNE would exert high cytotoxicity because it would not be bound to ECM. The possibility of such secondary anticancer effects of oxidative stress and lipid peroxidation, in particular of HNE, influencing cancer stem cells through modification of their microenvironment could be important in determining cancer progression versus efficiency of cancer therapies applied and should be, therefore, further studied. We hope that the preliminary results presented will encourage also other researchers to study this important but not well recognized topic.

\section{Acknowledgements}

This article is dedicated to the memory on our dear friend and colleague Professor Janos Feher who suddenly passed away on May 28th, 2010.

The authors wish to thank the reviewers for stimulating and constructive comments.

The study was supported by grant no. 524/07/1511 of the Grant Agency of the Czech Republic, by Croatian MSES and by COST B35 Action.

\section{REFERENCES}

Balic M (2009) Disseminated tumor cells as biomarkers for breast cancer. Biom Medicine 3: 215-217.

Balic M, Lin H, Young L, Hawes D, Giuliano A, McNamara G, Datar RH, Cote RJ (2006) Most early disseminated cancer cells detected in bone marrow of breast cancer patients have a putative breast cancer stem cell phenotype. Clin Cancer Res 12: 5615-5621.

Borrirukwanit K, Lafleur MA, Mercuri FA, Blick T, Price JT, Fridman R, Pereira JJ, Leardkamonkarn V, Thompson EW (2007) The type I collagen induction of MT1-MMP-mediated MMP-2 activation is repressed by alphaVbeta 3 integrin in human breast cancer cells. $M a$ trix Biol 26: 291-305.

Borovic S, Sunjic I, Wildburger R, Mittelbach M, Waeg G, Zarkovic $\mathrm{N}$ (2007) Lipid peroxidation end product as a modulator of cell growth. In: Progress in cell growth process research. Hayashi T, ed, pp 187-208. Nova Science Publishers Inc, New York.

Boyd NF, McGuire V (1991) The possible role of lipid peroxidation in breast cancer risk. Free Radic Biol Med 10: 185-190.

Bradford MM (1976) A rapid and sensitive method for the quantitation of microgram quantitites of protein utilizing the principle of protein-dye binding. Anal Biochem 72: 248-254.

Braun S, Vogl FD, Naume B, Janni W, Osborne MP, Coombes RC, Schlimok G, Diel IJ, Gerber B, Gebauer G, Pierga JY, Marth C, Oruzio D, Wiedswang G, Solomayer EF, Kundt G, Strobl B, Fehm T, Wong GYC, Bliss J, Vincent-Salomon A, Pantel K (2005) A pooled analysis of bone marrow micrometastasis in breast cancer. $N$ Engl J Med 353: 793-802.

Brown E, McKee T, diTomaso E, Pluen A, Seed B, Boucher Y, Jain RK (2003) Dynamic imaging of collagen and its modulation in tumors in vivo using second-harmonic generation. Nat Med 9: 796-800.

Cazacu M, Oniu T, Lungoci C, Mihailov A, Cipak A, Klinger R, Weiss T, Zarkovic N (2003) The influence of Isorel on the advanced colorectal cancer. Cancer Biother Radiopharm 18: 27-34.

Charafe-Jauffret E, Monville F, Ginestier C, Dontu G, Birnbaum D, Wicha MS (2008) Cancer stem cells in breast: current opinion and future challenges. Pathobiology 75: 75-84.

Ciz M, Cizova H, Pejchalova K, Jancinova V, Goshev I, Mihaylova B, Nosal R, Lojek A (2009) Interactions of oxidatively modified calf skin collagen with platelets and phagocytes. Neuroendocrinol Lett 30: 128-132.
Condell RA, Sakai N, Mercado RT, Larenas E (1988) Quantitation of collagen fragments and gelatin by deconvolution of polarimetry denaturation curves. Coll Relat Res 8: 407-418.

Danielsen CC (1982) Precision method to determine denaturation temperature of collagen using ultraviolet difference spectroscopy. Coll Relat Res 2: 143-150.

Dontu G, Abdallah WM, Foley JM, Jackson KW, Clarke MF, Kawamura MJ, Wicha MS (2003) In vitro propagation and transcriptional profiling of human mammary stem/progenitor cells. Genes Dev 17: 1253-1270.

Esterbauer H, Schaur RJ, Zollner H (1991) Chemistry and biochemistry of 4-hydroxynonenal, malonaldehyde and related aldehydes. Free Radic Biol Med 11: 81-128.

Fillmore CM, Kuperwasser C (2008) Human breast cancer cell lines contain stem-like cells that self-renew, give rise to phenotypically diverse progeny and survive chemotherapy. Breast Cancer Res 10: R25.

Gudjonsson T, Ronnov-Jessen L, Villadsen R, Rank F, Bissell MJ, Petersen OW (2002) Normal and tumor-derived myoepithelial cells differ in their ability to interact with luminal breast epithelial cells for polarity and basement membrane deposition. J Cell Sci 115: 3950 .

Hadden J (1999) The immunology and immunotherapy of breast cancer: an update. Int J Immunopharmacol 21: 79-101.

Hajj M, Wicha MS, Benito-Hernandez A, Morrison SJ, Clarke MF (2003) Prospective identification of tumorigenic breast cancer cells. Proc Natl Acad Sci USA 100: 3983-3988.

Horenstein MS, Vander Heide RS, L'Ecuyer TJ (2000) Molecular basis of anthracycline-induced cardiotoxicity and its prevention. Mol Genet Metab 71: 436-444.

Imlay JA, Chin SM, Linn S (1988) Toxic DNA damage by hydrogen peroxide through the Fenton reaction in vivo and in vitro. Science 240: 640-642.

Ingber DE (2008) Can cancer be reversed by engineering the tumor microenvironment? Semin Cancer Biol 18: 356-364.

Jemal A, Siegel R, Ward E, Murray T, Xu J, Smigal C, Thun MJ (2006) Cancer Statistics 2006. CA Cancer I Clin 56: 106-130.

Kökoğlu E, Karaarslan I, Karaarslan HM, Baloğlu H (1994) Alterations of serum lipids and lipoproteins in breast cancer. Cancer Lett 82: $175-178$.

Komsa-Penkova R, Koynova R, Kostov G, Tenchov B (1999) Discrete reduction of type I collagen thermal stability upon oxidation. Biophys Chem 83: 185-195.

Kreuzer T, Grube R, Zarkovic N, Schaur RJ (1998) 4-Hydroxynonenal modifies the effects of serum growth factors on the expression of the c-fos proto-oncogene and the proliferation of HeLa carcinoma cells. Free Radic Biol Med 25: 42-49.

Li L, Xie T (2005) Stem cell niche: structure and function. Annu Rev Cell Dev Biol 21: 605-631.

Li XY, Ota I, Yana I, Sabeh F, Weiss SJ (2008) Molecular dissection of the structural machinery underlying the tissue-invasive activity of membrane type-1 matrix metalloproteinase. Mol Biol Cell 19: 32213233 .

Miller EJ, Rhodes RK (1982) Preparation and characterization of the different types of collagen. Methods Ensymol 82 (Part A): 33-64.

Morrison BJ, Schmidt CW, Lakhani SR, Reynolds BA, Lopez JA (2008) Breast cancer stem cells: implications for therapy of breast cancer. Breast Cancer Res 10: 210.

Pinner S, Sahai E (2008) PDK1 regulates cancer cell motility by antagonising inhibition of ROCK1 by RhoE. Nat Cell Biol 10: 127-137.

Poli G, Schaur RJ (2000) 4-Hydroxynonenal in the pathomechanisms of oxidative stress. IUBMB Life 50: 315-321.

Ponti D, Costa A, Zaffaroni N, Pratesi G, Petrangolini G, Coradini D, Pilotti S, Pierotti MA, Daidone MG (2005) Isolation and in vitro propagation of tumorigenic breast cancer cells with stem/progenitor cell properties. Cancer Res 65: 5506-5511.

Privalov PL, Tiktopulo EI (1970) Thermal conformational transformation of tropocollagen. I. Calorimetric study. Biopolymers 9: 127-139.

Ray G, Husain SA (2001) Role of lipids, lipoproteins and vitamins in women with breast cancer. Clin Biochem 34: 71-76.

Sabeh F, Ota I, Holmbeck K, Birkedal-Hansen H, Soloway P, Balbin M, Lopez-Otin C, Shapiro S, Inada M, Krane S, Allen E, Chung D, Weiss SJ (2004) Tumor cell traffic through the extracellular matrix is controlled by the membrane-anchored collagenase MT1-MMP. J Cell Biol 167: 769-781.

Sabeh F, Shimizu-Hirota R, Weiss SJ (2009) Protease-dependent versus independent cancer cell invasion programs: three-dimensional amoeboid movement revisited. I Cell Biol 185: 11-19.

Sayre LM, Zelasko DA, Harris PL, Perry G, Salomon RG, Smith MA (1997) 4-Hydroxynonenal-derived advanced lipid peroxidation end products are increased in Alzheimer's disease. I Neurochem 68: 2092-2097.

Schaur RJ, Dussing G, Kink E, Schauenstein E, Posh K, Kukovetz E, Egger G (1994) The lipid peroxidation product 4-hydroxynonenal is formed and is able to attract rat neutrophils in vivo. Free Radic Res 20: $365-373$. 
Selley ML, Bourne DJ, Bartlett MR,Tymms KE, Brook AS, Duffield AM, Ardlie NG (1992) Occurrence of (E)-4-hydroxy-2-nonenal in plasma and synovial fluid of patients with rheumatoid arthritis and osteoarthritis. Ann Rheum Dis 51: 481-484.

Sirchia R, Luparello C (2005) Collagen-induced differential expression of an RNA polymerase subunit by breast cancer cells. Biochimie 87: 669-672.

Sovic A, Borovic S, Loncaric I, Kreuzer T, Zarkovic K, Vukovic T, Wäg G, Hrascan R, Wintersteiger R, Klinger R, Zurak N, Schaur RJ, Zarkovic N (2001) The carcinostatic and proapoptotic potential of 4-hydroxynonenal in HeLa cells is associated with its conjugation to cellular proteins. Anticancer Res 21: 1997-2004.

Spradling A, Drummond-Barbosa D, Kai T (2001) Stem cells find their niche. Nature 414: 98-104.

Toyokuni S, Okamoto K, Yodoi J, Hiai H (1995) Persistent oxidative stress in cancer. FEBS Lett 358: 1-3.

Tumbar T, Guasch G, Greco V, Blanpain C, Lowry W, Reudl M, Fuchs E (2004) Defining the epithelial stem cell niche size. Nature 303: 359-363.

Uchida K (2003) 4-Hydroxy-2-nonenal: a product and mediator of oxidative stress. Prog Lipid Res 42: 318-343.

Uchida K, Szweda LI, Chae HZ, Stadtman ER (1993) Immunochemical detection of 4-hydroxynonenal protein adducts in oxidized hepatocytes. Proc Natl Acad Sci USA 90: 8742-8746.

Wallace DG, Condell RA, Donovan JW, Paivinen A, Rhee WM, Wade $\mathrm{SB}$ (1986) Multiple denaturational transitions in fibrillar collagen. Biopolymers 25: 1875-1895.
Wolf K, Mazo I, Leung H, Engelke K, von Andrian UH, Deryugina EI, Strongin AY, Bröcker EB, Friedl P (2003) Compensation mechanism in tumor cell migration: mesenchymal-amoeboid transition after blocking of pericellular proteolysis. I Cell Biol 160: 267-277.

Yoritaka A, Hattori N, Uchida K, Tanaka M, Stadtman ER, Mizuno Y (1996) Immunohistochemical detection of 4-hydroxynonenal protein adducts in Parkinson disease. Proc Natl Acad Sci USA 93: 2696-2701.

Zarkovic K (2003a) 4-Hydroxynonenal and neurodegenerative diseases. Mol Aspects Med 24: 293-303.

Zarkovic N (2003b) 4-Hydroxynonenal as a bioactive marker of pathopysiological processes. Mol Aspects Med 24: 281-291.

Zarkovic N, Ilic Z, Jurin M, Scahur RJ, Puhl H, Esterbauer H (1993) Stimulation of HeLa cell growth by physiological concentrations of 4-hydroxynonenal. Cell Biochem Funct 11: 279-286.

Zarkovic N, Zarkovic K, Schaur RJ, Stolc S, Schlag G, Redl H, Waeg G, Borovic S, Loncaric I, Juric G, Hlavka V (1999) 4-Hydroxynonenal as a second messenger of free radicals and growth modifying factor. Life Sci 65: 1901-1904.

Zarkovic N, Cipak A, Cindric M, Waeg G, Borovic Sunjic S, Mrakovcic L, Jaganjac M, Kolenc D, Andrisic L, Gveric Ahmetasevic S, Katusic A, Cherkas A, Juric Sekhar G, Wildburger R, Zarkovic K (2009) 4-Hydroxynonenal-protein adducts as biomarkers of oxidative stress, lipid peroxidation and oxidative homeostasis. In Free radicals, health and lifestyle. Caporossi D, Pigozzi F, Sabatini S, eds, pp 37-45. Medimond Srl, Bologna, Italy. 